\title{
Hearing Impaired Students' Self-Efficacy on the Utilization of Assistive Technology in Federal College of Education (Special) Oyo
}

\author{
Aderonke Kofo Soetan, Amos Ochayi Onojah, Tawakalit Bukola Alaka, Adenike Janet \\ Aderogba \\ Department of Educational Technology, Faculty of Education \\ University of Ilorin, Nigeria
}

\begin{abstract}
s
The use of hearing assistive technology has been widely accepted in education and its penetration has transformed teaching and learning across the curriculum. This study examined students' self-efficacy on the utilization of hearing assistive technology for learning in Federal College of Education (Special) Oyo. Specifically, the study (i) assessed the hearing assistive technology that are functioning for hearing impaired students, (ii) ascertained the self-efficacy of hearing impaired students towards the utilization of hearing assistive technology, and (iii) determined the influence of gender on self-efficacy of hearing impaired students towards the utilization of hearing assistive technology. This study adopted descriptive research design of quantitative survey type; 250 hearing impaired students were sampled. The findings established that Telephone adaptations, TV decoder, Computer, Personal amplification, Telecommunication Device for the Deaf (TDD), Hearing Aid and Audiometer are more functional to the respondents and There was no significant difference between male and female hearing impaired students' attitude towards the utilization of hearing assistive technology for learning. The study concluded that assistive technology enhances students' self-efficacy. This implies that motivating students with disabilities learnings, give them sense of belonging so that they could also partake in things around their vicinity effectively. It was therefore recommended that schools should employ Educational Technologists that can facilitate effective use of assistive technology tools to supplement classroom teaching.
\end{abstract}

\section{Introduction}

Education can also be defined as a process of acquiring knowledge through study or imparting knowledge by way of instructions or some other practical procedures. Specifically, education helps and guides individuals to transform from one class to other [4]. Education transcends what takes places within the four walls of the classroom. Special Education is defined as a formal special educational training given to people (children and adult) with special needs, who fall into the categories: the disable, the disadvantaged and the gifted (National Policy on Education (FRN), 2013). Thus, special education deals with the education of the disabled who may have visual impairment, hearing impairment, physical and health impairment, intellectual disability, emotionally disturbance, speech impairment or learning disability. Although the gifted are also among the special educational needs.

Technology has opened many educational doors to children, particularly with disabilities. Assistive technology has been defined by numerous scholars but all are pointing to the same thing. Assistive technology is technology used by individuals with disabilities in order to perform functions that might otherwise be difficult or impossible [20].

Assistive Technology includes a broad range of hardware and software tools to transmit information to an individual in the manner most accessible to them. Assistive Technology devices include: mobility aids (wheelchairs, scooters, walkers, canes and crutches), hearing aids, talking calculator, phonetic spelling software, Braille machine, cochlear implants, visual alert systems and much more. Assistive Technology often encouraged schools, parents and educators as tools to assist students with special needs by providing a compensatory value, to remediate learning problems and to promote personal independence. These technologies range from simple spellcheckers to more complex speech recognition systems and educational software [15].

With the development of digital and wireless technologies, more and more devices are becoming more available to help people with hearing loss or a voice, speech or language disorder to communicate more meaningfully and participate more fully in their daily activities. It supports people with disabilities or their caregivers to help them select, acquire or use adaptive devices. Such services include functional evaluations, training on devices, product demonstration and equipment purchasing or leasing [13]. 
Assistive technology can provide equality between visually impaired individuals and their sighted peers within the emerging information society. With the aids of the appropriate technological devices, visually impaired persons can independently access, process, store and transmit the same information handled by sighted people. With technology, an individual who is physically unable to speak can communicate with spoken language. Using a portable voice synthesizer, a student can ask and respond to questions in the 'regular' classroom. Hearing assistive technology can also enable effective sound processing, overcoming a physical barrier that may have forced placement in a special segregated classroom or required a full-time instructional aide or interpreter to provide 'a voice'.

Assistive technology devices offer people with disabilities the opportunity not just to use computers but to use computers to complete tasks that were previously not possible for them. For example, hearing aids and cochlea implants are designed to hear sounds better and louder which will in turn enhance communication and learning skills. The purpose of assistive technology is to work around specific deficits, rather than fixing them and helping people with learning differences reach their full potential and live satisfying rewarding lives [12].

Assistive Technology (AT) can be classified into three. The classifications can be being done in terms of complexity of the technology as low, medium or high AT. Low technology devices are less sophisticated and in-expensive tools. They are relatively easy to use and often people do not realise that these modifications are within the definition of assistive technology. Examples include book holder, braille text, colour filters, markers, pencil grip, key guard and weighted pen. Secondly, the Mid-Tech devices are like battery operated devices or simple electronics devices. Others are simple mechanical devices such as books on tape, electronic spell checker, portable keyboard and word processor. Lastly, High-Tech devices involve complex electronics and usually contain micro-computer components for storage and retrieval of information. They are expensive and require on-going maintenance and extensive training. Examples of this include word prediction software, talking calculators and hearing aids or listening device [10].

Koganuramath and Chowkimath [8] opined that access to information has a major problem for the disabled, but in this $21^{\text {st }}$ century, Information and Communication Technology (ICT) along with assistive technologies have helped to reduce the digital divide between sighted and blind by providing information on the desktop. In an educational context, accessibility to course ware is an issue for the disabled learners. Onojah et al. [11] established that there is relationship between access and utilization of social media. The accessibility of the content can be provided to students with disabilities via an interface that is compatible with the various enabling (hardware/software) technologies which need to run in conjunction with the course-ware programme. The functionality of the interface includes navigation, searching, indexing, bookmarking and note-taking.

Sanaman [14] posited that, in a library, assistive technology devices may be as simple as a magnifying glass or it can be as sophisticated as a computer work station with software which can facilitate user with disabilities to scan a book and hear it read loud followed with highlighted text on a monitor screen. Similarly, libraries can add workstations configured according to the needs of the specific user groups like provision of speech recognition software for the blind to control computer or enter the text via their voices; hearing aids and cochlear implant to facilitate communication between the deaf and others who are not.

Self-efficacy is basically an expectation that by personal effort one can achieve a desired given situation. Feelings of self-efficacy are based on four sources of information, namely; performance accomplishments, vicarious experience, verbal persuasion and emotional arousal [1]. In the specific context of assistive technology, efficacy could be described as imparting or improving the functional capability of students with disabilities [16]. The perception of self-capabilities or self-efficacy has been identified as key factors affecting thought patterns and performance in a wide variety of tasks [16]. Self-efficacy perceptions influence choice of activity, task perseverance, level of effort expended, and ultimately, degree of success achieved [1].

Students with disabilities need more than ability and skills in order to perform successfully; they also need the sense of efficacy to use them well and to regulate their learning. Self-efficacy beliefs consist of the degree to which students with disabilities can control their level of performance and their environment in specific contexts [6]. There are a number of possible factors underpinning the finding of optimistic efficacy beliefs in certain students with disabilities. Estimations of self-efficacy can be construed as a form of metacognition and students with disabilities have been found to display significant metacognitive [3].

Gender is the range of characteristics pertaining to, and differentiating between masculinity (male) and femininity (female). Kelly [7] expressed that girls have low esteem in the area of computer science than boys. Vekiri [17] findings indicate that girls perceive less support and encouragement for computer activities from their parents compared to boys. Young [19] found out that boys spend more time on the computers both at home and at school than girls. Also, computers are seen as males' domain rather than females. All these would seem to provide incontrovertible evidences, that indeed, 
there is a lower female interest and proficiency towards the computer and assistive technologies in general than male counterparts. Litt [9] findings indicate that boys seem to report higher levels of ICT literacy than girls. Kelly [7] extrapolated on the general believe that things are no longer as complex and involving social interactions as it used to be.

\section{Statement of the Problem}

Wehmeyer et al. [18] found that exposing students with disabilities to flexible technologies helped increase their functional skills, take advantage of their strengths, and compensate for their weaknesses. Hence, teachers should be encouraged to use technology for both normal and special needs students.

There are a lot of disabled students who have the right to get the best education as their normal peers. These students deserve the same right with their normal peers in the Nigerian education system [5]. Students with disabilities usually have the same level of mental capability as the normal hearing students in terms of studying but are only lacking other capability and not intelligence level [5]. However, problems could occur for such students if the teaching technique used by the instructors in teaching them is the same as used for normal hearing students. Hence, by using assistive technologies, students could access all that is needed for learning on their own suitable way and at their own pace [2].

\section{Research Questions}

The study provided answers to the following research questions:

i. What are the hearing assistive technology that are functioning for hearing impaired students?

ii. What is the level of self-efficacy of hearing impaired students towards the utilization of hearing assistive technology?

iii. How does gender influence self-efficacy of hearing impaired students towards the utilization of hearing assistive technology?

\section{Research Hypothesis}

$\mathrm{H}_{01}$ : There is no significant difference between male and female hearing impaired students' selfefficacy towards the utilization of hearing assistive technology for learning.

\section{Methodology}

This chapter focused on the methodology that was adopted in the study. They include; research design, sample and sampling techniques, research instrument.

\subsection{Research Design}

This study adopted descriptive research design of quantitative survey type. This enabled the researcher to collect information as it exists without any form of manipulation.

\subsection{Sample and Sampling Techniques}

A sample of 250 hearing impaired students of the institution was randomly selected for the study. Male and female of hearing impaired students from all levels in the Federal College of Education (Special) Oyo was considered.

\subsection{Research Instrument}

The study was carried out using researcherdesigned questionnaire to gather necessary information from respondents. The questionnaire titled "Students' Self-Efficacy on the Utilization of Hearing Assistive Technology for Learning" contain three (3) sections. Section A seek information about demographic data of the respondents such as gender, level and department. Section B elicit information on hearing assistive technology that are functioning for Hearing Impaired (HI) students and the expected mode of response was Likert-type response-mode of Functional and Not Functional. Section $\mathrm{C}$ have items seeking information about the hearing impaired students' self-efficacy on the utilization of assistive technology for learning and the expected mode of response was Likert-type response-mode of Strongly Agree (SA), Agree (A), Disagree (D) and Strongly Disagree (SD).

\subsection{Data Analysis Techniques}

The data obtained from the questionnaire was coded and subjected to inferential and descriptive statistics. Percentage, frequency count and mean was used to answer the research questions while ttest statistics was used to test research hypotheses. Data collected was coded using Statistical Package for Social Sciences (SPSS) version 25.0 windows.

\subsection{Data Analysis and Results}

The chapter present the finding of the questionnaire administered in Federal College of Education (Special) Oyo, Oyo State. The main purpose of this study was to analyze the Students' Attitude to, And Self-Efficacy On the Utilization of Hearing Assistive Technology for Learning in Federal College of Education (Special) Oyo, Oyo State. The table below show the general analysis of the data collected across the school. 


\section{Results}

Table 1 revealed that female students have the highest frequency and percentage of 129 which is $48.4 \%$, while male students was $129(51.6 \%)$.

Table 1. Percentage Distribution by Gender

\begin{tabular}{lcc}
\hline Gender & Frequency & $\begin{array}{c}\text { Percentage } \\
(\boldsymbol{\%})\end{array}$ \\
\hline Male & 121 & 48.4 \\
Female & 129 & 51.6 \\
Total & 250 & 100.0 \\
\hline
\end{tabular}

Table 2 shows the educational level of the students. It is observed that $80(32 \%)$ of the respondents were in NCE 1,110 representing $44 \%$ of the respondents were in NCE 2, while 60 respondents representing $24 \%$ were in NCE 3.

Table 2. Percentage Distribution by Level

\begin{tabular}{lcc}
\hline Level & Frequency & $\begin{array}{c}\text { Percentage } \\
(\boldsymbol{\%})\end{array}$ \\
\hline NCE 1 & 80 & 32.0 \\
NCE 2 & 110 & 44.0 \\
NCE 3 & 60 & 24.0 \\
Total & 250 & 100.0 \\
\hline
\end{tabular}

Research Question 1: What is the hearing assistive technology that are functioning for hearing impaired students?

Table 3 presents result on respondents' functioning of hearing assistive technology. It indicated that $41.6 \%$ representing 104 respondents stated that their Alert / Signal systems is functioning while $58.4 \%$ representing 146 respondents said the item is not functioning. Item 2: showed that $56 \%$ representing 140 respondents said the item was functioning while $44 \%$ representing 110 respondents said the item is not functioning. Item 3: showed that $51.6 \%$ representing 129 respondents said the item functional while $48.4 \%$ representing 121 respondents said the item is not functional. Item 4: showed that $40.8 \%$ representing 102 respondents said the item functional while $59.2 \%$ representing 148 respondents said the item is not functional. Item 5: showed that $62.4 \%$ representing 156 respondents said the item functional while $37.6 \%$ representing 94 respondents said the item is not functional.
Table 3. Respondents Response on the functioning of Hearing Assistive Technology

\begin{tabular}{|c|c|c|c|}
\hline $\mathbf{S} / \mathbf{N}$ & $\begin{array}{l}\text { Hearing Assistive } \\
\text { Technologies }\end{array}$ & $\begin{array}{l}\text { Functional } \\
(\%)\end{array}$ & $\begin{array}{c}\text { Not } \\
\text { Functional } \\
(\%)\end{array}$ \\
\hline 1 & $\begin{array}{l}\text { Alert/ } \\
\text { systems }\end{array}$ & $\begin{array}{c}104 \\
(41.6 \%)\end{array}$ & $146(58.4 \%)$ \\
\hline 2 & $\begin{array}{l}\text { Telephone } \\
\text { adaptations }\end{array}$ & $140(56 \%)$ & $110(44 \%)$ \\
\hline 3 & TV decoder & $129(51.6 \%)$ & $121(48.4 \%)$ \\
\hline 4 & TV amplifier & $102(40.8 \%)$ & $148(59.2 \%)$ \\
\hline 5 & Computer & $156(62.4 \%)$ & $94(37.6 \%)$ \\
\hline 6 & $\begin{array}{l}\text { Personal } \\
\text { amplification }\end{array}$ & $131(52.4 \%)$ & $119(47.6 \%)$ \\
\hline 7 & $\begin{array}{l}\text { FM Amplification } \\
\text { system }\end{array}$ & $112(44.8 \%)$ & $138(55.2 \%)$ \\
\hline 8 & $\begin{array}{l}\text { Infrared } \\
\text { amplification } \\
\text { system }\end{array}$ & $119(47.6 \%)$ & $131(52.4 \%)$ \\
\hline 9 & $\begin{array}{l}\text { Induction } \\
\text { systems }\end{array}$ & $101(40.4 \%)$ & $149(59.6 \%)$ \\
\hline 10 & $\begin{array}{l}\text { Telecommunication } \\
\text { Device for the Deaf } \\
\text { (TDD) }\end{array}$ & $156(62.4 \%)$ & $94(37.6 \%)$ \\
\hline 11 & Hearing Aid & $163(65.2 \%)$ & $87(34.8 \%)$ \\
\hline 12 & Audiometer & $173(69.2 \%)$ & $77(30.8 \%)$ \\
\hline
\end{tabular}

Furthermore, it was showed that $52.4 \%$ representing 131 respondents said the item was functioning while $47.6 \%$ representing 119 respondents said the item is not functioning. Item 7 : showed that $44.8 \%$ representing 112 respondents said the item functional while $55.2 \%$ representing 138 respondents said the item is not functional. Item 8: showed that $47.6 \%$ representing 119 respondents said the item functional while $52.4 \%$ representing 131 respondents said the item is not functional. Item 9: showed that $40.4 \%$ representing 101 respondents said the item functional while $59.6 \%$ representing 149 respondents said the item is not functional. Item 10: showed that $62.4 \%$ representing 156 respondents said the item functional while $37.6 \%$ representing 94 respondents said the item is not functional. Item 11: showed that $65.2 \%$ representing 163 respondents said the item functional while $34.8 \%$ representing 87 respondents said the item is not functional. Item 12: showed that $69.2 \%$ representing 173 respondents said the item functional while $30.8 \%$ representing 77 respondents said the item is not functional.

From the findings, it can be summarized that Telephone adaptations, TV decoder, Computer, Personal amplification, Telecommunication Device for the Deaf (TDD), Hearing Aid and Audiometer are more functional to the respondents. 
Table 4. Respondents Response on Self-Efficacy on the Utilization of Hearing Assistive Technology for Learning

\begin{tabular}{|c|c|c|c|c|c|c|}
\hline $\mathbf{S} / \mathbf{N}$ & ITEMS & SA (\%) & A (\%) & D (\%) & SD (\%) & Mean \\
\hline 1. & $\begin{array}{l}\text { I can use hearing } \\
\text { assistive technology } \\
\text { when I cannot } \\
\text { perform the activity } \\
\text { on my own }\end{array}$ & $65(26)$ & $85(34)$ & $65(26)$ & $35(14)$ & 2.72 \\
\hline 2. & $\begin{array}{l}\text { I can use the hearing } \\
\text { assistive technology } \\
\text { every time if } \\
\text { required by the } \\
\text { situation }\end{array}$ & $70(28)$ & $67(26.8)$ & $82(32.8)$ & $31(1.4)$ & 3.16 \\
\hline 3. & $\begin{array}{l}\text { I believe that the use } \\
\text { of hearing assistive } \\
\text { technology will } \\
\text { develop my } \\
\text { listening skills }\end{array}$ & $78(31.2)$ & $45(18.0)$ & $100(40)$ & $27(10.8)$ & 3.61 \\
\hline 4. & $\begin{array}{l}\text { I am willing to use } \\
\text { hearing assistive } \\
\text { technology for } \\
\text { learning }\end{array}$ & $72(28.8)$ & $47(18.8)$ & $105(42)$ & $26(10.4)$ & 2.77 \\
\hline 5. & $\begin{array}{l}\text { With the use of } \\
\text { hearing assistive } \\
\text { technology, I can do } \\
\text { things } \\
\text { independently }\end{array}$ & $63(25.2)$ & $70(28)$ & $83(33.2)$ & $34(13.6)$ & 2.65 \\
\hline 6. & $\begin{array}{l}\text { By using hearing } \\
\text { assistive } \\
\text { technology, the rate } \\
\text { at which I perform } \\
\text { activities will be } \\
\text { faster }\end{array}$ & $61(24.4)$ & $84(33.6)$ & $56(22.4)$ & 49(19.6) & 2.63 \\
\hline 7. & $\begin{array}{l}\text { By using hearing } \\
\text { assistive } \\
\text { technology, the rate } \\
\text { at which I perform } \\
\text { activities will be } \\
\text { much easier }\end{array}$ & $61(24.4)$ & $82(32.8)$ & $52(20.8)$ & $55(22)$ & 2.60 \\
\hline 8. & $\begin{array}{l}\text { When I have an } \\
\text { academic problem, I } \\
\text { will seek a relevant } \\
\text { solution using } \\
\text { hearing assistive } \\
\text { technology }\end{array}$ & $61(24.4)$ & $74(29.6)$ & $56(22.4)$ & $59(23.6)$ & 2.55 \\
\hline 9. & $\begin{array}{l}\text { I believe that I can } \\
\text { learn easily using } \\
\text { hearing assistive } \\
\text { technology }\end{array}$ & $69(27.6)$ & $73(29.2)$ & $56(22.4)$ & $52(20.8)$ & 2.64 \\
\hline 10. & $\begin{array}{l}\text { I can figure out } \\
\text { anything when using } \\
\text { hearing assistive } \\
\text { technology }\end{array}$ & $84(33.6)$ & $61(24.4)$ & $53(21.2)$ & $52(20.8)$ & 2.71 \\
\hline 11. & $\begin{array}{l}\text { If I practice every } \\
\text { day, I could develop } \\
\text { skills when using } \\
\text { hearing assistive } \\
\text { technology }\end{array}$ & $74(29.6)$ & $53(21.2)$ & $63(25.2)$ & $60(24)$ & 2.56 \\
\hline
\end{tabular}




\begin{tabular}{|c|c|c|c|c|c|c|}
\hline 12. & $\begin{array}{l}\text { I believe that } \\
\text { hearing assistive } \\
\text { technology can } \\
\text { enhance my } \\
\text { assimilation skills }\end{array}$ & $47(18.8)$ & $53(21.2)$ & $60(24)$ & $90(36)$ & 2.23 \\
\hline 13. & $\begin{array}{l}\text { I believe that the } \\
\text { application of } \\
\text { hearing assistive } \\
\text { technology for } \\
\text { learning will not be } \\
\text { difficult for me }\end{array}$ & 74(29.6) & $44(17.6)$ & $35(14)$ & $97(38.8)$ & 2.38 \\
\hline 14. & $\begin{array}{l}\text { I can continue to use } \\
\text { the hearing assistive } \\
\text { technology, even if } \\
\text { it is tiring and } \\
\text { difficult }\end{array}$ & $71(28.4)$ & $34(13.6)$ & $57(22.8)$ & $88(35.2)$ & 2.35 \\
\hline 15. & $\begin{array}{l}\text { I believe that my } \\
\text { brain can be develop } \\
\text { when using hearing } \\
\text { assistive technology }\end{array}$ & $66(26.4)$ & $40(16)$ & $53(21.2)$ & $91(36.4)$ & 2.32 \\
\hline & GRAND MEAN & & & & & 2.66 \\
\hline
\end{tabular}

Research Question 2: What is the level of selfefficacy of hearing impaired students towards the utilization of hearing assistive technology?

Table 4 showed that Item 1: showed that 150 respondents representing $60 \%$ agreed that they can use hearing assistive technology when I cannot perform the activity on my own While 100 respondents representing $40 \%$ disagreed with the statement. Item 2 shows that 137 respondents representing $54.8 \%$ agreed that they can use the hearing assistive technology every time if required by the situation while 113 respondents representing $34.2 \%$ disagreed with this statement. Item 3 showed that 123 respondents representing $49.2 \%$ agreed that they believe that the use of hearing assistive technology will develop my listening skills while 127 respondents representing $50.8 \%$ disagreed with the statement. Item 4 showed $47.6 \%$ of the total respondents 119 agreed with they are willing to use hearing assistive technology for learning while $52.4 \%$ disagreed with the statement.

Item 5 showed that 133 respondents representing $78.2 \%$ agreed that with the use of hearing assistive technology, I can do things independently while 177 respondents representing $(46.8 \%)$ disagreed with the statement. Item 6 showed that 145 respondents representing $58 \%$ agreed that by using hearing assistive technology, the rate at which I perform activities will be faster while 105 respondents representing (42\%) disagreed with the statement. Item 7 showed that 143 respondents representing $57.2 \%$ agreed that by using hearing assistive technology, the rate at which I perform activities will be faster while 107 respondents (42.8\%) disagreed with the statement. Item 8 showed that 135 respondents representing $54 \%$ agreed that When they have an academic problem, they will seek a relevant solution using hearing assistive technology while 115 respondents representing (46\%) disagreed with the statement.

Item 9 showed that 142 respondents representing $56.8 \%$ agreed that they believe that they can learn easily using hearing assistive technology while 108 respondents representing (43.2\%) disagreed with the statement. Item 10 showed that 145 respondents representing 58\% agreed that they can figure out anything when using hearing assistive technology while 105 respondents representing $(42 \%)$ disagreed with the statement. Item 11: showed that 127 respondents representing $50.8 \%$ agreed that If they practice every day, they could develop skills when using hearing assistive technology While 123 respondents representing $49.2 \%$ disagreed with the statement. Item 12 shows that 100 respondents representing $100 \%$ agreed that they believe that hearing assistive technology can enhance my assimilation skills while 150 respondents representing $60 \%$ disagreed with this statement. Item 13 showed that 118 respondents representing $69.2 \%$ agreed that with the use of hearing assistive technology, my listening skills could be developed while 77 respondents representing $30.8 \%$ disagreed with the statement.

Item 14 showed $42 \%$ of the total respondents 105 agreed that they can continue to use the hearing assistive technology, even if it is tiring and difficult while $58 \%$ disagreed with the statement. Item 15 showed that 106 respondents representing $42.4 \%$ agreed that they believe that their brain can be develop when using hearing assistive technology while 91 respondents representing (36.4\%) disagreed with the statement. The Grand Mean Score on the self-efficacy of hearing impaired 
students towards the utilization of hearing assistive technology for learning was 2.66 which is greater than the benchmark of 2.50 (since the response mode was for Likert scale). Thus, Hearing Impaired Students have good self-efficacy towards the use of Assistive technology for learning.

\section{Hypothesis Testing}

$\mathrm{H}_{01}$ : There is no significant difference between male and female hearing impaired students' self-efficacy on the utilization of hearing assistive technology for learning.

In an attempt to determine whether there was any significant difference between male and female hearing impaired students' self-efficacy on the utilization of hearing assistive technology for learning, independent t-test was used for the null hypothesis as shown in Table below.

Table 5. T-test on male and female hearing impaired students' self-efficacy on the utilization of hearing assistive technology for learning

\begin{tabular}{lccccccc}
\hline & & & & Df & T & $\begin{array}{c}\text { Sig. } \\
(\mathbf{2 -} \\
\text { tailed }\end{array}$ & $\begin{array}{c}\text { Remark } \\
\text { S }\end{array}$ \\
$\begin{array}{l}\text { Gende } \\
\text { r }\end{array}$ & N & Mean & SD & & & ) & \\
\hline Male & 12 & 3.669 & 0.8102 & 24 & & & \\
& 1 & 4 & 3 & 8 & & & \\
& & & & & 0.10 & .918 & Accepted \\
& & & & & 3 & & \\
Female & 12 & 3.658 & 0.7958 & & & & \\
& 9 & 9 & 9 & & & & \\
\hline
\end{tabular}

Table 5 showed that degree of freedom $(\mathrm{df})=$ $248, \mathrm{t}=0.103, \mathrm{p}=0.918$. This means that the hypothesis is accepted. This was as a result of tvalue of 0.103 , resulting in significant $p$ value of 0.918 which is greater than 0.05 alpha level. The hypothesis is accepted. There was no significant difference between male and female hearing impaired students' self-efficacy on the utilization of hearing assistive technology for learning in Federal College of Education (Special) Oyo, Oyo State.

\section{Discussions}

From the findings, it is indicated that Telephone adaptations, TV decoder, Computer, Personal amplification, Telecommunication Device for the Deaf (TDD), Hearing Aid and Audiometer are more functioning to the respondents. This is in support by Ologe (2014) who observed that structure and functioning of hearing apparatus are always complex and prone to damage or diseases that may end up incapacitating the hearing acuity of disables people. Bakare [21] described hearing impairment as absence of normal hearing. Hearing impairment is the type of impairment that affects person's auditory and may be as a result of congenital or adventitious injury. Assistive technology coupled with auditory oral training have accounted for the huge success recorded in recent times, on enabling persons with hearing impairment to regain hearing, use speech and learn effectively.

Furthermore, the findings established that the hearing impaired students have good self-efficacy towards the use of Assistive technology for learning. This is in support of Stone et al. [16] which revealed that in the specific context of assistive technology, efficacy could be described as imparting or improving the functional capability of students with disabilities. The perception of self-capabilities or self-efficacy has been identified as key factors affecting thought patterns and performance in a wide variety of tasks [16]. Self-efficacy perceptions influence choice of activity, task perseverance, level of effort expended, and ultimately, degree of success achieved [1].

Students with disabilities need more than ability and skills in order to perform successfully; they also need the sense of efficacy to use them well and to regulate their learning. Self-efficacy beliefs consist of the degree to which students with disabilities can control their level of performance and their environment in specific contexts [6]. There are a number of possible factors underpinning the finding of optimistic efficacy beliefs in certain students with disabilities. Estimations of self-efficacy can be construed as a form of metacognition and students with disabilities have been found to display significant metacognitive [3].

Hypothesis one stated that there is no significant difference between male and female hearing impaired students' self-efficacy on the utilization of hearing assistive technology for learning. The hypothesis was accepted and this established that there was no significant difference between male and female hearing impaired students' self-efficacy on the utilization of hearing assistive technology for learning in Federal College of Education (Special) Oyo, Oyo State. The finding was not in support by Meelissen (2005) which revealed that girls seem to have a lower self-efficacy compared to boys especially in more complicated computer tasks. Also, the finding was not in support of Litt [9] which indicated that boys seem to report higher levels of ICT literacy than girls.

\section{Conclusion}

The study concluded that assistive technology enhances students' self-efficacy. This implies that motivating students with disabilities learnings, give them sense of belonging so that they could also partake in things around their vicinity effectively. It was therefore recommended that schools should employ Educational Technologists that can facilitate 
effective use of assistive technology tools to supplement classroom teaching.

Assistive technology is one of the key elements to advancing inclusion of people with disabilities in combination with other supports such as personal assistance, sign language interpreters and barrier removal; meaning that, access to assistive technology and accessible technology for people with disabilities is critical for many to access and benefit from education.

\section{Recommendations}

Based on the findings of this research, the following recommendations are made:

1. Parents and school administrators should know about assistive technologies and assist them in the usage instead of prohibiting students from using such equipment.

2. Students should be allowed to use assistive technology equipment services in the school, if they cannot be allowed to use it in their dormitories.

3. Schools should employ Educational Technologists that can facilitate effective use of assistive technology tools to supplement classroom teaching.

\section{References}

[1] Bandura, A. (2001). Guide for Constructing SelfEfficacy Scales. (Unpublished manuscript available from the author).

[2] Berndsen, M., \& Luckner, J. (2012). Supporting Students Who Are Deaf or Hard of Hearing in General Education Classrooms: A Washington State Case Study. In Communication Disorders Quartely (pp. 33, 111-118).

[3] Bong, N., \& Skaalvik, E. M. (2003). Academic SelfConcept and Self-Efficacy, and Intrinsic Interest through Proximal Self-Motivation. Journal of Personality and Social Psychology.

[4] Bosick, N., Starcher, K., Kelly, K., \& Hapke, N. (2008). Accessibility and Universal Design in Common Wealth of Learning (COL,Ed), Education for a digital world: Advice guidelines and Effective practice from the Globe. Vancouver, Canada: http://www.colfinder.net/ materials/Education for a Digital World/ Education for a Digital World complete.pdf.

[5] FRN. (2013). Federal Republic of Nigeria: National Policy on Education. NERDC Press.

[6] Gignac, G. E., \& Szodorai, E. T. (2016). Effect Size Guidelines for Individual Differences Researchers. In Personality and Individual Differences.

[7] Kelly, R. (2000). Working with Web Quests. In Teaching Exceptional Children.
[8] Koganuramath, M. M., \& Choukimath, P. A. (2009). Learning Resource Centre For the Visually Impaired Students in the Universities to Foster Inclusive Education. International Conference on Academic Libraries (pp. 619625). Delhi, India. Retrieved from http://crl.du.ac.in/ ica109/papers/index_files/ical104_215_458_2_RV.pdf.

[9] Litt, E. (2013). Measuring User' Internet skills: A review of past assessments and a look toward the future. New Media and Society.

[10] Microsoft. (2012). Types of Assistive Product. Retrieved From: http://www.microsoft.com/enable/at/ types.

[11] Onojah A. O., C. O. Olumorin, M. V. Adegbija and T. O. Babalola. (2019). Perception of undergraduate students on the utilisation of flipped classroom for learning in south-west Nigeria. Malaysian Journal of Distance Education 21(1): 95-112. https://doi.org/10.21315/mjde2019.21.1.6

[12] Osatuyi, N. O. (2003). Science and Technology in the Education of People with Special Needs. Journal of Science and Technology in Special Education, 2, 143-158.

[13] Rehabtool. (2014). Assistive Tools. Retrieved From: http://www.rehabtool.com.

[14] Sanaman, G. (2014). Assistive Technologies for People with Disabilities in National Capital Region Libraries of India. University of Nebraska Press: http://digitalcommons.unl.edu/libphilprac.

[15] Scherer, M., \& Stefano, F. (2017). Assistive Technology Assessment Handbook. CRC Press, Taylor and Francis Group.

[16] Stone, V. I., Lockett, M., Usiak, D. J., \& Arthanat, S. (2010). Beyond Technology Transfer: Quality of Life Impacts from $R \& D$ outomes. In Assistive Technology Outcomes and Benefits, 6(1), 87-128.

[17] Vekiri, I. (2010). Boys' and Girls' ICT believe: Do Teachers matter? In Computers and Education, 55, 16-23.

[18] Wehmeyer, M., Palmer, S., Smith, S., Davies, D., \& Stock, S. (2008). The Efficacy of Technology Use by People with Intellectual Disability: A Single-Subject Design Meta-Analysis. Journal of Special Education Technology, 23, 21-30.

[19] Young, B. L. (2000). Gender Differences in Students' attitudes towards Computer. Journal of Research on Computing Education, Winter.

[20] Zascavage, V., \& Winterman, K. (2009). What middle School Educators should know about Assistive Technology and Universal Design Learning? Middle School Journal, 40(4), 46-52.

[21] Bakare, A.O., (2013). Socio-demographic variables as predictors of psychological well-being amongst the adolescents with hearing impairment in Southwest Nigeria. IFE PsychologIA : An International Journal, Volume 21, Number 1, 1 March 2013, pp. 245-259(15) 